\title{
Reproductive biology of Rhaphiodon vulpinus (Ostariophysi: Cynodontidae) in the Tocantins River Basin, Brazil
}

\author{
Andréa L. Neuberger, Elineide E. Marques, Carlos S. Agostinho, and Rafael J. de Oliveira
}

In order to evaluate aspects of the reproductive biology of Rhaphiodon vulpinus in the Upper and Middle Tocantins River, samples were taken monthly from October, 1999 through September, 2001, by means of gill nets. Males, which were more abundant than females $\left(\chi^{2} 146.87: \mathrm{df}=1: \mathrm{p}<0.05\right)$, matured at a smaller size. The reproductive period of the species extended essentially from November through January, with a peak of activity in November. Fecundity, with an estimated mean value of 98,185 oocytes, varied from 38,177 to 215,841 oocytes, and it did not correlate with the length of the individual female analyzed $(\mathrm{r}=0.4663: \mathrm{p}=0.206)$. Relative fecundity was 130.6 oocytes $/ \mathrm{g}$ total weight. Mature oocytes had a mean diameter of $0.98 \mathrm{~mm}$, corresponding to a volume of $0.50 \mathrm{~mm}^{3}$.

Visando avaliar aspectos da biologia reprodutiva de Rhaphiodon vulpinus, foram realizadas coletas mensais no período de outubro de 1999 a setembro de 2001, no alto e médio rio Tocantins utilizando redes de espera. Os machos foram mais abundantes que as fêmeas $\left(\chi^{2} 146,87: \mathrm{gl}=1: \mathrm{p}<0,05\right)$ e alcançaram o tamanho de primeira maturação em comprimentos menores. O período reprodutivo da espécie se estendeu, essencialmente, de novembro até janeiro, com pico de atividade no primeiro mês. A fecundidade, com valor médio estimado de 98185 ovócitos, variou de 38177 a 215841 . A correlação entre o comprimento padrão das fêmeas e a fecundidade não foi significativa $(\mathrm{r}=0,4663$ : $\mathrm{p}=0,206)$. A fecundidade relativa foi de 130,6 ovócitos/g de peso total. O diâmetro médio dos ovócitos maduros foi $0,98 \mathrm{~mm}$, correspondendo a volume de $0,50 \mathrm{~mm}^{3}$.

Key words: Sex ratio, First maturation, Reproduction, Fecundity.

\section{Introduction}

Fishes of the subfamily Cynodontinae are piscivorous, and are easily recognized by the strongly oblique mouth and a pair of well-developed teeth in their dentition (Silvano et al., 2001).

Rhaphiodon vulpinus Spix \& Agassiz, 1829, the most widely distributed member of the Cynodontidae, can be distinguished from other species of the group by its strongly elongated, laterally compressed body (Toledo-Piza, 2000). As a generalist piscivore, its morphology is adapted to capturing prey at the surface or middle depths (Almeida et al., 1997); it inhabits the upper part of the water column (Freire \& Agostinho, 2001), and is considered a migratory species (Ferreira \& Caramaschi, 2005; Agostinho et al., 2003). R. vulpinus occurs in the Amazon, Paraguay-Paraná and Uruguay River basins (Toledo-Piza, 2000).

Although $R$. vulpinus is a widely distributed, commonly caught species, important in commercial fisheries in some Bra- zilian reservoirs (Okada et al., 2005), information on general aspects of its biology, particularly its reproduction, is sparse. According to Suzuki \& Agostinho (1997), reproduction is one of the most important aspects of the biology of a species, because its success depends on recruitment and consequently the long-term maintenance of its populations. In this context, we sought in this study to describe aspects of the reproduction of males and females of this species, analyzing the sex ratio, size at first gonadal maturity, reproductive period, fecundity, and size of the oocytes of $R$. vulpinus in the Upper and Middle Tocantins River.

\section{Materials and Methods}

Collections were carried out monthly from October, 1999 through September, 2001, in the upper and middle parts of the Tocantins River basin. The 21 sampling points were chosen to include three different environments (lakes, tributaries, and the main channel of the Tocantins River) (Fig. 1).

Núcleo de Estudos Ambientais, Universidade Federal do Tocantins, Rua 03, Quadra 17, Jardim dos Ipês, 77500-000 Porto Nacional, TO, Brazil.emarques@uft.edu.br 
The fish were caught with gill nets with mesh sizes of 2.4 to $16.0 \mathrm{~cm}$ between opposite knots. The nets were set out for periods of $24 \mathrm{~h} /$ locality/month, and were emptied after 8,16 , and $22 \mathrm{~h}$. The fish were placed on ice and taken to the laboratory. The date and sampling location, standard length $(\mathrm{cm})$, total weight $(0.1 \mathrm{~g})$, sex, and gonadal weight $(0.01 \mathrm{~g})$ were recorded. The gonad maturity stages were classified macroscopically on the basis of transparency, blood capillaries, color, and in females, the presence and size of oocytes (Table 1). Portions of mature ovaries were collected, weighed, fixed in $4 \%$ neutral formalin, and later preserved in $70 \%$ alcohol.

The proportion of males to females was determined for each sampling period and length class, and tested by $\chi^{2}$.

The size at first maturity $\left(\mathrm{L}_{50}\right)$, which represents the point at which $50 \%$ of the individuals begin their reproductive cycle, and the length at which all individuals are capable of participating actively in the reproductive process $\left(\mathrm{L}_{100}\right)$, were estimated separately for males and females from the frequency of adult individuals $(f r)$ per standard length class $(x)$, according to the method described by Vazzoler (1996) and adjusted by the following equation:

$$
f r=1-e^{-a \cdot x^{b}}
$$

Individuals with immature gonads were considered as young, and those with gonads in other stages of maturity were considered as adults. Resting individuals were excluded from the analyses, because macroscopic classification of gonads to this maturity stage probably includes individuals that have already passed through a reproductive period (true resting stage) and those that are preparing for reproduction for the first time.

The reproductive cycle was assessed based on the monthly frequency of maturity stages, monthly mean gonadosomatic index (GSI), which expresses gonad weight as a percentage $t$ of the total weight of the individuals, and the index of reproductive activity (IRA), used by Tos et al. (1997) and calculated as follows:

$$
\mathrm{IRA}=\frac{\operatorname{lnNi}\left(\frac{\mathrm{ni}}{\sum \mathrm{ni}}+\frac{\mathrm{ni}}{\mathrm{Ni}}\right) \frac{\mathrm{GSIi}}{\mathrm{GSIe}}}{\ln \mathrm{Nm}\left(\frac{\mathrm{nm}}{\sum \mathrm{ni}}+1\right)} * 100
$$

$\mathrm{Ni}=$ number of individuals in unit $\mathrm{i}$;

$\mathrm{ni}=$ number of reproductive individuals in sample unit $\mathrm{i}$;

$\mathrm{Nm}=$ number of individuals in largest sample unit;

$\mathrm{nm}=$ number of reproductive individuals in the sample unit with the largest number of individuals;

GSIi = mean GSI of reproductive individuals in sampling unit i;

GSIe $=$ highest individual value of the GSI.
$\mathrm{GSI}=100 \mathrm{Wg} \cdot W t^{-1}$.

Reproductive activity, as measured by the IRA, was assessed according to the following scale: null (IAR $=0$ ), incipient $(0<\operatorname{IAR} \leq 5)$, moderate $(5<10)$, and intense (IAR $>10$ ).

Female gonads were dissociated and a sub-sample taken for fecundity estimation. In each sub-sample, all the vitellogenic oocytes present in the sample were counted and their diameters measured. The total number of oocytes $(\mathrm{N})$ in each ovary was estimated by $N=n W \mathrm{~g} \cdot w^{-1}$ where $n$ is the number of oocytes in the sub-sample, $W \mathrm{~g}$ is the total gonad weight, and $w$ is the sub-sample gonad weight (Vazzoler, 1996). The relative fecundity was obtained from the ratio between the total number of vitellogenic oocytes and the total weight of the fish. Twenty oocytes from the most-developed lot had their diameters measured. Oocyte volumes were calculated from the values for mean diameter. The relation between individual standard length and fecundity was determined using Pearson's correlation coefficient. Water level data for Tocantins River were provided by Agência Nacional de Águas (ANA).

\section{Results}

A total of 2711 individuals (1671 males and 1040 females) were analyzed. Males predominated significantly overall

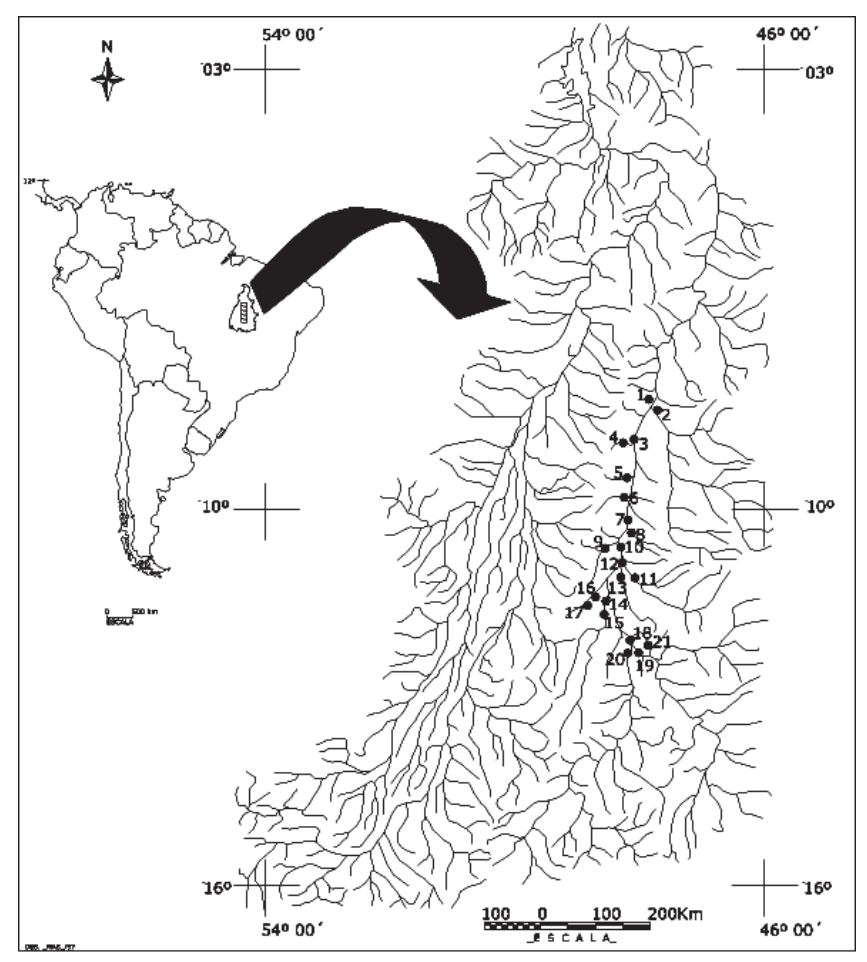

Fig. 1. Sample places location. Points number 1, 3, 7, 12, 14, 18 and $20=$ Tocantins river; $2=$ Sono river; $4=$ Lajeadinho river; $5=$ Santa Luzia river; $6=$ Mangues river; $8=$ Areias river; $9=$ Crixás river; $10=$ Capivara Lagoon; $11=$ Manuel Alves river; 13 = São Valério river; 15 = Santa Tereza river; 16 = Dionízio Lagoon; 17 = Água Branca Lagoon; 19 = Paranã river and $21=$ Bonita Lagoon. 
Table 1. Macroscopic gonadal characterization of female and male Rhaphiodon vulpinus in different stages of gonadal maturity and mean gonadosomatic index values (GSI). The values of GSI for immature stages were not calculated because of the small size of the gonads.

\begin{tabular}{|c|c|c|}
\hline $\begin{array}{l}\text { Gonad } \\
\text { maturity } \\
\text { stage }\end{array}$ & Females & Males \\
\hline Immature & $\begin{array}{l}\text { Ovaries filiform, translucent, } \\
\text { small, positioned next to the } \\
\text { dorsal wall, no signs of } \\
\text { vascularization; oocytes not } \\
\text { visible. }\end{array}$ & $\begin{array}{l}\text { Testicles small, filiform, } \\
\text { positioned next to dorsal } \\
\text { wall. }\end{array}$ \\
\hline $\begin{array}{l}\text { Early } \\
\text { maturation }\end{array}$ & $\begin{array}{l}\text { Ovaries pink, vascularization } \\
\text { very fine; small oocytes } \\
\text { (opaque granules) present. } \\
\text { GSI mean }=1.06\end{array}$ & $\begin{array}{l}\text { Testicles larger than in } \\
\text { previous stage; small } \\
\text { quantities of sperm } \\
\text { present. GSI mean }=0.11\end{array}$ \\
\hline Maturation & $\begin{array}{l}\text { Ovaries light reddish brown, } \\
\text { capillary network extensive; } \\
\text { various sizes of oocytes } \\
\text { present (opaque granules). } \\
\text { GSI mean }=4.69\end{array}$ & $\begin{array}{l}\text { Testicles developed, } \\
\text { lobated; membrane } \\
\text { ruptures under pressure, } \\
\text { releasing viscous, milky } \\
\text { sperm. GSI mean }=0.32\end{array}$ \\
\hline Mature & $\begin{array}{l}\text { Ovaries greenish brown, } \\
\text { occupying nearly entire } \\
\text { coelomic cavity, turgid; } \\
\text { oocytes large and opaque. } \\
\text { GSI mean }=6.96\end{array}$ & $\begin{array}{l}\text { Testicles turgid, whitened, } \\
\text { occupying large part of } \\
\text { coelomic cavity; } \\
\text { membrane ruptures under } \\
\text { gentle pressure, releasing } \\
\text { less-viscous sperm than in } \\
\text { previous stage. GSI mean } \\
=0.72\end{array}$ \\
\hline $\begin{array}{l}\text { Partially } \\
\text { spent }\end{array}$ & $\begin{array}{l}\text { Ovaries smaller than in } \\
\text { previous stage, with some } \\
\text { small points of hemorrhage; } \\
\text { many large, opaque oocytes, } \\
\text { and few oocytes in process of } \\
\text { being absorbed. GSI mean = } \\
5.51\end{array}$ & $\begin{array}{l}\text { Testicles smaller than in } \\
\text { previous stage, areas of } \\
\text { slight hemorrhage present, } \\
\text { butr mostly still turgid; } \\
\text { sperm flows with a slight } \\
\text { touch. GSI mean }=0.50\end{array}$ \\
\hline Spent & $\begin{array}{l}\text { Ovaries flaccid, with } \\
\text { distended membranes and } \\
\text { hemorrhagic appearance, } \\
\text { smaller in size; few oocytes } \\
\text { present, in process of being } \\
\text { absorbed (appearing } \\
\text { granular). GSI mean }=1.71\end{array}$ & $\begin{array}{l}\text { Testicles flaccid, with } \\
\text { hemorrhagic appearance; } \\
\text { membrane does not } \\
\text { rupture under pressure. } \\
\text { GSI mean }=0.16\end{array}$ \\
\hline Resting & $\begin{array}{l}\text { Ovaries small although larger } \\
\text { than immature ones, } \\
\text { translucent, with weak } \\
\text { vascularization, positioned } \\
\text { next to dorsal wall; no } \\
\text { oocytes observed. GSI }=0.67\end{array}$ & $\begin{array}{l}\text { This stage was not defined } \\
\text { for males of this species. }\end{array}$ \\
\hline
\end{tabular}

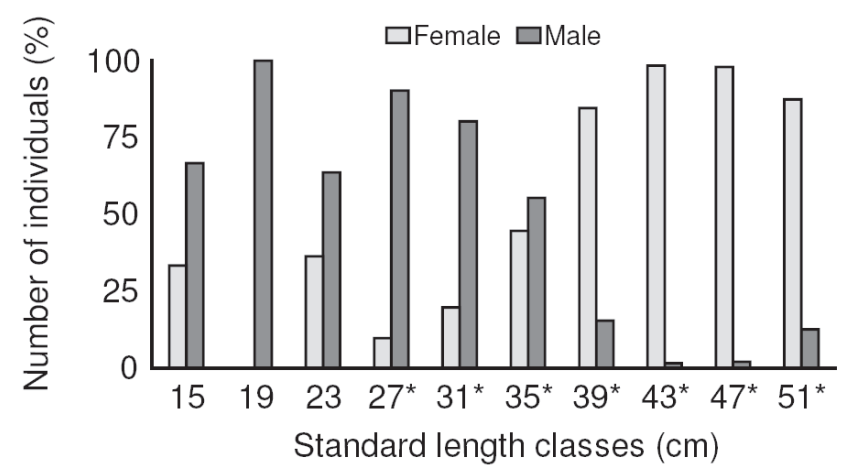

Fig. 2. Distribution of males and females of Rhaphiodon vulpinus, by standard length class. Asterisks indicate significant differences in sex ratio. $\left(1.6: 1.0 ; \chi^{2}=146.87: \mathrm{p}<0.05\right)$. Males predominated at the smaller lengths $(26.0$ to $37.0 \mathrm{~cm}$ ), whereas females dominated the larger lengths ( 37.0 to $52.0 \mathrm{~cm}$ ) (Fig. 2). The values of $\mathrm{L}_{50}$ and $\mathrm{L}_{100}$ differed between the sexes: 27.0 and $38.6 \mathrm{~cm}$ for females, and 21.7 and $32.2 \mathrm{~cm}$ for males, respectively (Fig. 3a-b).

The description of the stages of gonadal maturity and the mean values of GSI for both sexes are presented in Table 1. Mature and partially spent individuals were considered as reproductive individuals.

The maximum GSI values were $22.5 \%$ for females and $9.9 \%$ for males. The highest frequencies of reproducing individuals and the highest values of the mean GSI were observed between October and February, for both sexes (Figs. 4a-d). Therefore, reproductively active females were recorded from October to March, and reproductively active males were recorded in all months except July and August (Fig. 4a,b). The values of the IRA, which combines these two variables with the size of the sample and the maximum values of the gonadosomatic index, showed that the females were reproductively active intensively during November and December, moderately in January, and incipiently in October, February and March (Fig. 4e). Male reproductive activity was moderate in
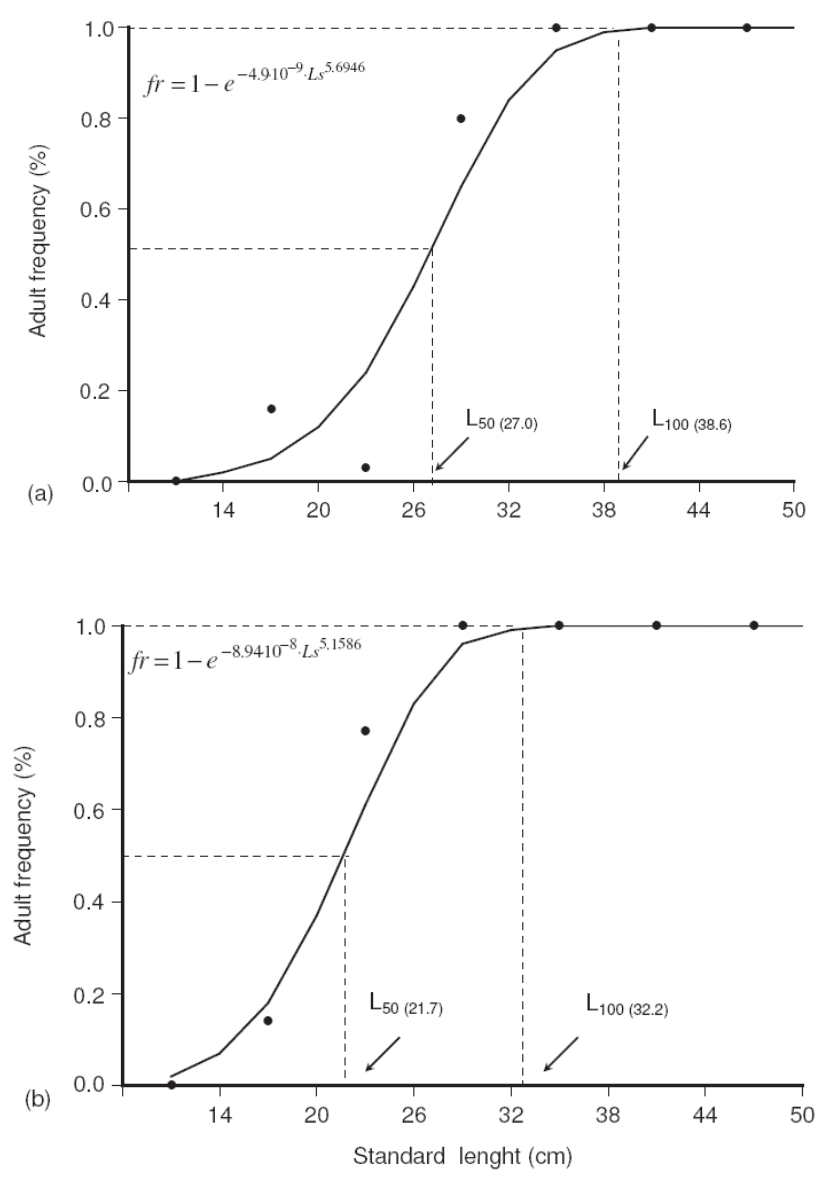

Fig. 3. Sexual maturity curve for females (a) and males (b) of Rhaphiodon vulpinus. 

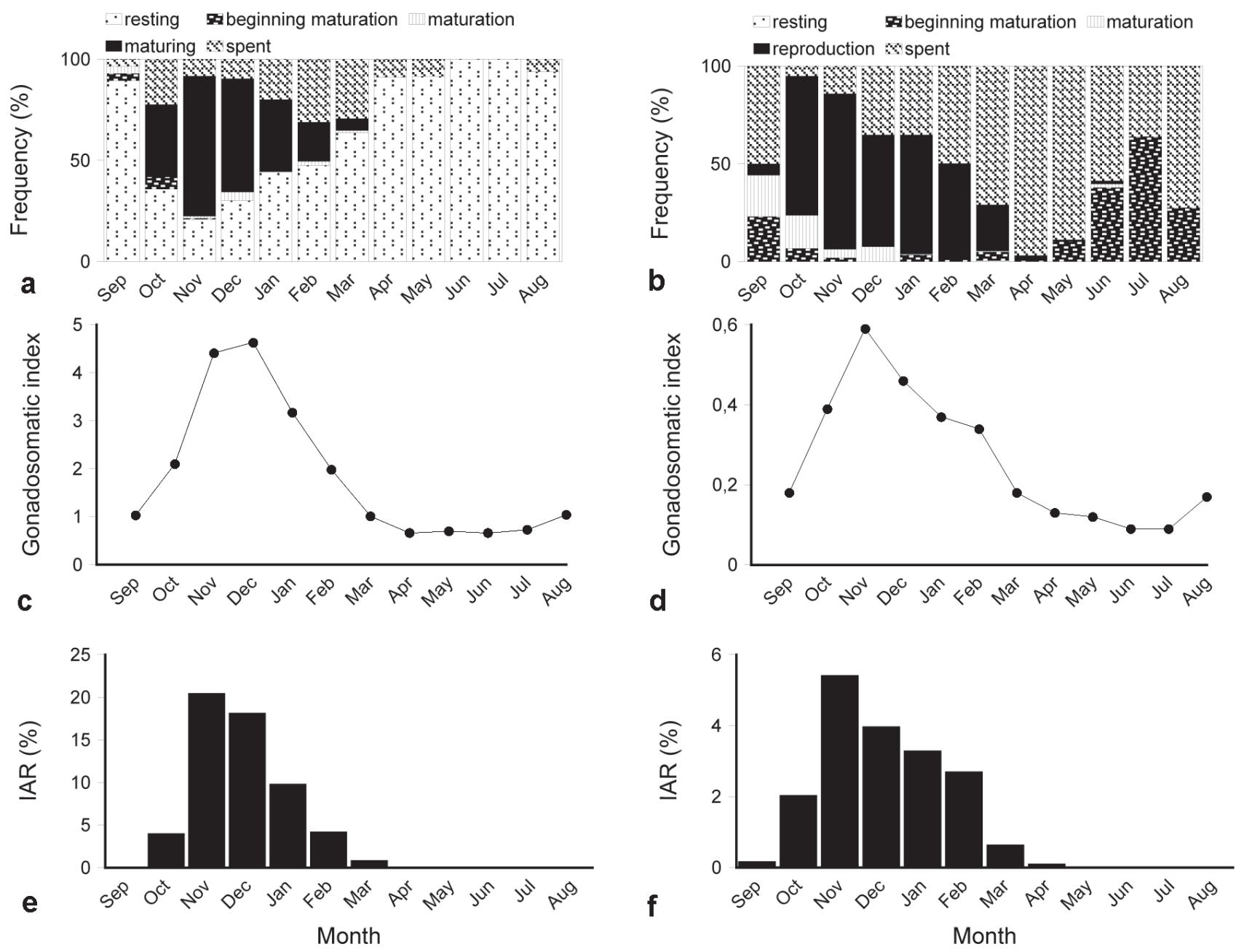

Fig. 4. Monthly variation of the frequency of gonadal maturity stages (a and b), mean gonadosomatic index (c and d), and index of reproductive activity (e and f) for females (a, c, e) and males (b, d, f) of Rhaphiodon vulpinus.

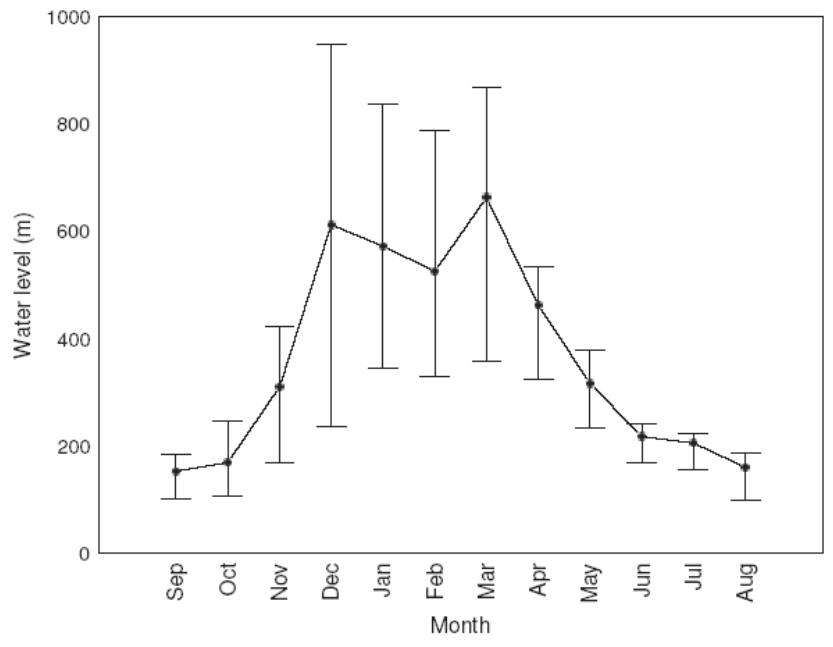

Fig. 5. Monthly Tocantins River water level (m) variation. Vertical bars $=$ minimum and maximum values; point $=$ mean values .
November, and incipient in the preceding (September and October) and subsequent months (December to April) (Fig. 4f). Thus, the reproductive period was longer for males than for females. Males are reproductively active from September to April and females from October to March. The maximum reproductive activity for both sexes was observed during

Table 2. Values of fecundity and oocyte size of Rhaphiodon vulpinus in the Tocantins river.

\begin{tabular}{lcccc}
\hline & \multicolumn{2}{c}{ Fecundity } & \multicolumn{2}{c}{ Oocytes } \\
\cline { 2 - 5 } Parameter & $\begin{array}{c}\text { Absolute } \\
\text { No. of eggs }\end{array}$ & $\begin{array}{c}\text { Relative } \\
\text { Eggs/g }\end{array}$ & $\begin{array}{c}\text { Diameter } \\
\mathrm{mm}\end{array}$ & $\begin{array}{c}\text { Volume } \\
\mathrm{mm}^{3}\end{array}$ \\
\hline Number & 10 & 10 & 10 & 10 \\
Mean & 98,185 & 130.64 & 0.98 & 0.50 \\
Standard deviation & 59,419 & 60.36 & 0.05 & 0.07 \\
Maximum & 215,841 & 223.69 & 1.04 & 0.60 \\
Minimum & 38,177 & 51.34 & 0.91 & 0.40 \\
\hline
\end{tabular}


increasing water level and at the beginning of the high-water period (Fig. 5).

The results of the counts and measurements of the vitellogenic oocytes of $R$. vulpinus are shown in Table 2. The mean fecundity was 98,185 oocytes, which represents 130.6 oocytes per gram of fish. The correlation between individual female length and fecundity was not significant $(r=0.4663$; $\mathrm{n}=9 ; \mathrm{p}=0.206$ ).

\section{Discussion}

According to Vazzoler (1996), the sex ratio in fishes varies during the life cycle, as a function of successive events, which act differently on the individuals of each sex. Mortality is one of the factors which can determine the predominance of one sex over the other at the different developmental stages. Another factor that can result in seasonal differences is segregation for reproduction. A predominance of females in the larger length classes suggests that females grow faster, and thus reach a larger size at a given age (Vazzoler, 1996).

According to Wootton (1991), the beginning of sexual maturity represents a critical transition in the life of an individual, because it adds a new demand to the previous needs for growth and survival. The size at first maturity can vary according to genetic differences (between the sexes), or as a result of different environmental conditions over the area where the species occurs, and in different years (Wootton, 1991; Vazzoler, 1996). Genetic differences may account for the smaller size of the males of $R$. vulpinus at sexual maturity.

In a study carried out in an upriver stretch of the Tocantins River, Ferreira \& Caramaschi (2005) found that males of $R$. vulpinus have their reproductive period between October and April. Data from the present study indicate that males are reproductively active from September to April. This difference in lengths of the reproductive period can be related to the sampled months. Ferreira \& Caramaschi (2005) did not sample in September. The Tocantins River has a well-defined hydrological regime. The high-water period extends from October through April (Ribeiro et al., 1995); i.e., the beginning of the flood stage coincides with the peak reproductive period of $R$. vulpinus. A similar association between the beginning of the flood stage and the reproductive migration and spawning of $R$. vulpinus was reported for the Paraná River basin, where it is reproductively active from October through January (Agostinho et al., 2003). As environmental conditions change during the year, the appropriateness of the environment for the initial stages of the life cycle changes. A fish must reproduce at the time of year when its production of viable descendants is maximized. The larvae must hatch in a medium that can provide appropriate food, protection from predators, and favorable abiotic conditions. Seasonal reproductive patterns in freshwater fishes living at low latitudes are frequently related to the effect of changes in water level (Wootton, 1991).

The maximum value of the GSI can provide indications about the reproductive investment of a species in the pro- duction of gametes. In the case of $R$. vulpinus, this value reached $22.5 \%$ of the body weight, a value considerably higher than thatof $16 \%$ found by Suzuki (1992) for the same species in the Paraná River basin.

The variation in fecundity and the diameter of the mature oocytes are extremely labile reproductive tactics, varying between reproductive periods, among individuals of the same size, and within the same reproductive period (Vazzoler, 1996). The size of the oocytes may also be related to latitude, as shown for families of marine fishes, for which oocyte size tends to increase with latitude (Wootton, 1991). This may explain the difference between the diameter of the mature oocytes of R. vulpinus in the Tocantins River $(0.98 \mathrm{~mm})$ and the value found by Vazzoler (1996) in the Paraná river (1.13 $\mathrm{mm})$.

The number of oocytes produced during a reproductive period may be determined as much by variables such as food availability, which increases recruitment of the oocytes in the vitellogenic phase, as by adverse factors that reduce the stock of vitellogenic oocytes by inducing atresia. One estimate of maximum fecundity, based on the largest females caught in the Tocantins River, gave a mean value of 391,000 oocytes, higher than that estimated for the Paraná river basin $(348,500$ oocytes; Agostinho et al., 2003).

A phenomenon common to many other species of fishes is that the males remain in intense reproductive activity for a longer period than do females. In R. vulpinus, spermatozoids can be recorded during nearly the entire year. Differences in the process of accumulating material (reserves), characteristic of oocyte development in relation to spermatogenesis and which determines the number and viability of the embryos, must be related to this.

The data obtained in the present study revealed that $R$. vulpinus can be considered a species with a "seasonal strategy" (sensu Winemiller, 1989). It has a cyclic reproduction, and the beginning of its reproductive cycle is associated with the flood regime.

\section{Acknowledgements}

We are grateful to our colleagues at the Núcleo de Estudos Ambientais (Neamb), Universidade Federal do Tocantins (UFT), for their assistance in the field and laboratory work. CNPq (Proc. 505321/2004-1) provided financial support, and Neamb/UFT logistical support. We thank Agência Nacional de Águas (ANA) for providing Tocantins River water level data, and Dr. Angelo Antônio Agostinho for reading the manuscript and for helpful suggestions. We are grateful to the anonymous reviewers for suggestions, to Maurício Alves da Silva for the map design, to Dr. Paulo Henrique Franco Lucinda for the suggestions.

\section{Literature Cited}

Agostinho, A. A., L. C. Gomes, H. I. Suzuki \& H. F. Júlio Jr. 2003. Migratory fish from the upper Paraná river basin, Brazil. Pp. 
19-99. In: Carolsfeld, J., B. Harvey, C. Ross \& A. Baer (Eds.). Migratory Fishes of South America: Biology, Fisheries and Conservation Status. Victoria, World Fisheries Trust, the World Bank and the International Development Research Centre, 372p.

Almeida, V. L. L., N. S. Hahn \& A. E. A. de M. Vazzoler. 1997. Feeding patterns in five predatory fishes of the high Paraná river floodplain (PR, Brazil). Ecology of Freshwater Fish, 6:123133.

Ferreira, M. F. N. \& E. P. Caramaschi. 2005. Aspectos da Estratégia Reprodutiva de Machos de Teleósteos na Área de Influência da Usina Hidrelétrica Serra da Mesa, Alto Rio Tocantins, GO. In: Nogueira, M. G., H. Raoul \& A. Jorcin. Ecologia de Reservatórios: impactos potenciais, ações de manejo e sistemas em cascata. São Carlos, RiMa, 472p.

Freire, A. G. \& A. A. Agostinho. 2001. Ecomorfologia de oito espécies dominantes da ictiofauna do reservatório de Itaipu (Paraná/ Brasil). Acta Limnológica Brasiliensia, 13(1):1-9.

Okada, E. K., A. A. Agostinho \& L. C. Gomes. 2005. Spatial and temporal gradients in artisanal fisheries: a case study of the Itaipu Reservoir, Brazil. Canadian Journal of Fisheries and Aquatic Sciences, 62:714-724.

Ribeiro, M. C. L. B., M. Petrere \& A. A. Juras. 1995. Ecological integrity and fisheries ecology of the Araguaia-Tocantins Rivers Basin, Brazil. Regulated Rivers: Research \& Management, 11: 325-350.

Silvano, R., O. Oyakawa, B. Amaral \& A. Begossi. 2001. Peixes do
Alto Rio Juruá (Amazônia, Brasil). São Paulo, EDUSP, 300p. Suzuki, H. I. 1992. Variações na morfologia ovariana e no desenvolvimento do folículo de espécies de peixes teleósteos da bacia do rio Paraná, no trecho entre a foz do rio Paranapanema e a do rio Iguaçu. Dissertação (Mestrado). Universidade Federal do Paraná. Curitiba. 140p.

Suzuki, H. I. \& A. A. Agostinho. 1997. Reprodução de peixes do reservatório de Segredo. Pp. 163-182. In: Agostinho, A. A. \& L. C. Gomes (Eds.). Reservatório de Segredo: Bases Ecológicas para o Manejo. Maringá, EDUEM, 387p.

Toledo-Piza, M. 2000. The Neotropical Fish Subfamily Cynodontinae (Teleostei: Ostariophysi: Characiformes): A Phylogenetic Study and a Revision of Cynodon and Rhaphiodon. American Museum of Natural History, 3286: 88pp.

Tos, C. D., A. A. Agostinho \& H. I. Suzuki.1997. Population structure and reproductive biology of Loricariichthys platymetopon (Siluriformes, Pisces) in upper Paraná river. Brazilian Archives of Biology and Technology, Curitiba-PR, 40(4):793-807.

Vazzoler, A. E. A. de M. 1996. Biologia da Reprodução de Peixes Teleósteos: Teoria e Prática. Maringá, EDUEM, 169p.

Winemiller, K. O. 1989. Patterns of variation in life history among South American fishes in seasonal environments. Oecologia, 81: 225-241.

Wootton, R. G. 1991. Ecology of Teleost Fishes. London, Chapman \& Hall, 404p.

Submitted February 2007

Accepted September 2007 